\title{
A Critical Investigation into the Impact of Intelligence upon Organizational Citizenship Behavior
}

\author{
Reza Sepahvand \\ The Assistant Professor of Management Department and the Faculty Member of Lorestan University \\ Email:mrezasep@yahoo.com \\ Seyed Keyvan Mousavi \\ The PhD candidate of Human Resource Management in Lorestan University \\ Email:mousavi_keivan@yahoo.com
}

\section{Doi:10.5901/mjss.2016.v7n3s3p319}

\section{Abstract}

\begin{abstract}
Nowadays, employees play a pivotal role in achieving the goals of the organizations and especially the quality of the services in service organizations. The current investigations have confirmed that the organizational intelligence and organizational citizenship behavior variables influence the performance of the employees and organizations substantially. This study aims to investigate the intelligence impact on organizational citizenship behavior among the nurses at the governmental hospitals in Kermanshah Province, Iran. The sample volume was determined 220 individuals by the means of Cochran Formula. In addition, the organizational intelligence questionnaire (Fulford Enz, 2009) as well as the organizational citizenship behavior (Lee \& Allen, 2002) were distributed among 220 individuals. The collected data were analyzed using LISREL and SPSS software. Based on the research findings, it could be concluded that organizational intelligence and its dimensions make a significant impact on organizational citizenship behavior at physical education offices in Kermanshah province, Iran.
\end{abstract}

Keywords: Organizational intelligence, organizational citizenship behavior, willingness to change, unity and accord

\section{Introduction}

Today, organizations operate in a dynamic, ambiguous and unsteady environment. One of the most conspicuous features of the present epoch is the dramatic and ongoing changes occurring in the social, political, economic, technological, transnational and cultural conditions (such as changes happening in attitude, ideology, and social values)(Kordnayij, A. (2004)). Under such difficult circumstances, the organizations which gain the customers' satisfaction and offer extra values to them can prosper. The quality of the services is one of the most critical factors for achieving this goal, especially, in service organizations. Besides, the quality of services is premised as one of the most important tools required to meet the customers' requirements and allegiance. Reichheld and Sasser (1990) stated that offering appropriate quality of services is one of the key strategies for the organizations to survive (Reichheld \& Sasser, (1990)). Hospitals and health care providers are postulated as the organizations in which the presented services are of a paramount importance. According to the patients' view, there are many problems in terms of the quality of services provided by hospitals to customers in Iran. Quality consists of two dimensions: the technical and functional dimensions. Technical quality refers to the tangible facets of the services and what is delivered to them. The functional quality refers to the non-tangible dimension of services, and how the services are provided. In particular, the functional quality refers to the behavior of the employees who offer the determinate service and how the employees interact with the customers during the process of presenting the services. In hospitals, nurses constitute the majority of the service providers interacting with the customers. Nurses' activities are associated with patients (customers). These activities are considered as a vital factor in developing the effective relationships with customers. Therefore, nurses' skills, attitudes and behavior are of a great importance; since, nurses are ultimately liable for providing the quality services expected by the patients. Organizational citizenship behavior is assumed as one of the most important factors that can employ the nurses' behaviors, attitudes and interactions in order to provide more quality services (Jafari \& Faghihi, (2009)). OCB is a kind of behavior which goes beyond the pre-defined formal behaviors by the organizations, which are not directly rewarded or recognized by the formal structures but are very important to the functional and operational success of the organization ((Hui et al, 2001),(Organ \& Konovsky, (1989))). According to the definition, it could be alleged that this kind of behavior 
influences the nurses' type of attitude and behavior, directs their performances toward the goals of the hospital, and finally affects the quality of the services provided for the patients. In this study, the impact of organizational intelligence upon the OCB was investigated.

\subsection{The Organizational Citizenship Behavior (OCB)}

The term "organizational citizenship behavior (OCB)" was introduced in 1983 by Organ for the first time. This concept emanated from Barnard's scripts in 1938 on the willingness to cooperate and Katz's studies on the performance as well as the spontaneous and innovative behaviors in 1964, 1966 and 1978. Since OCB is not a part of the individuals' formal role, it is considered as a behavioral index to respond to the relationships among the colleagues (Dyne \& Ang, (1998)). Organ defined the OCB as the behaviors which are not a part of the organizational official duties but make an impact on the organization performance (Organ, (1988)). This type of behavior is supposed as an extra-role behavior standing against the intra-role behavior. The intra-role behaviors refer to the kind of behaviors expressed in the organizational official roles and duties description, identified by the official system of the organization and finally rewarded. However, the extra-role behaviors signify the occupational behaviors beyond the employees' official roles. Besides, these behaviors are arbitrary and are not usually considered in the formal reward system (Hui et al, 1999); consequently, they are such behaviors beyond their usual occupational duties. Among these types of behaviors, we can mention avoiding the unnecessary conflicts, helping the colleagues in the workplace, and enduring the conditions imposed on the organization's involvement in the organizational activities (Robbins, 2001).

\subsection{Dimensions of Organizational Citizenship Behavior}

Since the interest to study the OCB grew, there has always been a lack of consensus on the literature review concerning the OCB. Podsakoff's investigations (2000) demonstrated that approximately 30 different types of organizational citizenship behavior have been identified (Podsakoff et al, 2000). Various dimensions including altruism, conscientiousness, courtesy, sportsmanship, and civic virtue have attracted the most attention (Podsakoff et al, 2000).

Altruism is regarded as the act of helping the colleagues in their tasks. We can mention leaving replacement with colleagues, contributing to other individuals' projects, helping the newcomers and low-skilled individuals and etc. (Podsakoff et al, 1996). Conscientiousness is premised as the optional behaviors going beyond the minimum requirements; for instance, a person who stays at work more than the normal limit or an employee who does not spend much time on resting and attends the work early. Respecting other people and courtesy refers to the behaviors which prevent stresses, tensions, and work problems in relation to other people. Accepting the opponent, respecting the colleagues' opinions without imposing are considered as the exemplar behaviors of this dimension. Sportsmanship includes behaviors such as tolerating the criticism, lack of complaining about the organization, and preferring the qualified individuals. Civil behavior or respecting the administrative values is the same as the tendency to participate in organizational life, to attend the meetings, and to read the updated information and bulletins (Organ \& Konovsky, (1989)).

Netemeyer (1997) expressed the organizational citizenship behavior within four categories which include: sportsmanship, civic virtue, conscientiousness and altruism. This study concentrates on these four features (Netemeyer et al, 1997).

Regarding the aforementioned dimensions, the characteristics of a good organizational citizen needs to be investigated. Robbins (2001) features a good organizational citizen as follows:

1. Expressing constructive ideas about teamwork and organization

2. Avoiding unnecessary conflicts

3. Helping the team members

4. Volunteering for the extra-role activities

5. Respecting and abiding by the laws and regulations

6. Enduring the harsh and imposed work conditions.

Thus, good citizenship seems to be able to improve the managers' and coworkers' ability so as to perform their tasks through planning, timing, and problem solving. Besides, the pioneer organizations at good citizenship behavior have an attractive working environment and are able to attract and retain the best people (MacKenzie et al, 1991). In previous studies, researchers have identified many factors influencing the organizational citizenship. 


\subsection{The Meta-Analysis of Organizational Citizenship Behavior}

The concept of $\mathrm{OCB}$, in the past 15 years, has been the subject of many researches, and its importance still continues to grow. The previous studies are mainly of three types. A series of studies have focused on predicting and experimenting with the antecedents of OCB. In this context, factors such as job satisfaction, organizational commitment, organizational identity, organizational justice, trust, types of leadership, and the relationship between the leader and follower have been proposed as the antecedents of OCB (Podsakoff et al, 2000). On the other hand, a series of studies have focused on the consequences of the OCB. In this context, factors such as organizational performance, organizational effectiveness, organizational success, customer satisfaction, customer loyalty, social capital, etc. have been proposed (Yoon \& Suh (2003)).

A small number of studies have focused exclusively on the OCB, for example, they have attempted to present a new definition of $\mathrm{OCB}$, determine its dimensions, or create standard scales for measuring this concept using factor analysis method (Yoon \& Suh (2003)).

The meta-analysis of organizational citizenship behavior studies

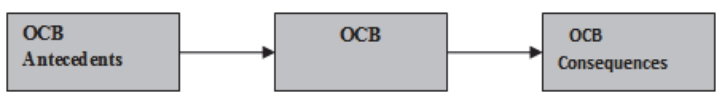

Table 1: The summary of the studies on OCB

\begin{tabular}{|c|c|c|c|}
\hline The research aims & $\begin{array}{l}\text { The researchers } \\
\text { and year }\end{array}$ & $\begin{array}{l}\text { The research } \\
\text { methodology }\end{array}$ & Summary of results \\
\hline \multirow{2}{*}{$\begin{array}{l}\text { Investigating the mediative role of trusting the } \\
\text { supervisor within the association between the } \\
\text { individual and organizational citizenship behavior } \\
\text { in university environments of Turkey }\end{array}$} & Alper Ertur & \multirow[b]{2}{*}{$\begin{array}{l}\text { Surveying } \\
\text { correlational }\end{array}$} & \multirow{2}{*}{$\begin{array}{l}\text { Trusting the supervisor plays a mediative role in the } \\
\text { association between the organizational justice and the } \\
\text { individual citizenship behavior as well as the association } \\
\text { between the organizational justice and the OCB }\end{array}$} \\
\hline & 2006 & & \\
\hline \multirow{2}{*}{$\begin{array}{l}\text { Investigating the mediative role of commitment in } \\
\text { the association between the citizenship behaviors } \\
\text { and the environmental feedback of the } \\
\text { organization }\end{array}$} & $\begin{array}{c}\text { Christina Norris } \\
\text { et.al }\end{array}$ & \multirow{2}{*}{$\begin{array}{l}\text { Surveying } \\
\text { correlational }\end{array}$} & \multirow{2}{*}{$\begin{array}{l}\text { Commitment plays a mediative role in the association } \\
\text { between the citizenship behaviors and the environmental } \\
\text { feedback of the organization }\end{array}$} \\
\hline & 2004 & & \\
\hline \multirow{2}{*}{$\begin{array}{l}\text { Investigating the mediative role of trust in the } \\
\text { association between the citizenship behaviors } \\
\text { and the organizational justice }\end{array}$} & Dennis Wat et.al & \multirow{2}{*}{$\begin{array}{l}\text { Surveying } \\
\text { correlational }\end{array}$} & \multirow{2}{*}{$\begin{array}{l}\text { Trust plays a mediative role in the association between } \\
\text { the citizenship behaviors and the organizational justice }\end{array}$} \\
\hline & 2004 & & \\
\hline \multirow{2}{*}{$\begin{array}{l}\text { Investigating the mediative role of trust in the } \\
\text { association between the citizenship behaviors } \\
\text { and the employees' demographic differences }\end{array}$} & $\begin{array}{c}\text { prithviraj } \\
\text { chattopadhyay }\end{array}$ & \multirow{2}{*}{$\begin{array}{l}\text { Surveying } \\
\text { correlational }\end{array}$} & \multirow{2}{*}{$\begin{array}{l}\text { Trust plays a defective mediative role in the association } \\
\text { between the citizenship behaviors and the employees' } \\
\text { demographic differences }\end{array}$} \\
\hline & 1999 & & \\
\hline \multirow{2}{*}{$\begin{array}{l}\text { Investigating the mediative role of commitment in } \\
\text { the association between the citizenship behaviors } \\
\text { and the procedural justice in the organization }\end{array}$} & $\begin{array}{l}\text { James j. Lavelle } \\
\text { et.al }\end{array}$ & \multirow{2}{*}{$\begin{array}{l}\text { Surveying } \\
\text { correlational }\end{array}$} & \multirow{2}{*}{$\begin{array}{l}\text { Commitment plays a mediative role in the association } \\
\text { between the citizenship behaviors and the procedural } \\
\text { justice in the organization }\end{array}$} \\
\hline & 2008 & & \\
\hline
\end{tabular}

Organizational Intelligence is a new concept in the context of organization and management literature. The organizational intelligence review of literature dates back to the 1990s, and it stems from knowledge management and organizational learning theory. However, organizational intelligence has been clearly and explicitly raised by Matsuda in an article titled "Intelligence organization, its importance as a process and a product" in the International Conference on Economics in Toky (Jafari, \& Faghihi, (2009)). He assumes organizational intelligence as a combination of human intelligence and mechanical intelligence. Organizational intelligence, as a mental ability, affects all areas of everyday human life (Brackett et al, 2004). Intelligence is the ability to learn and apply what has been learned in order to adapt to new situations and solve new problems. The term "intelligence" implies a certain abstract invisible quality intelligence with the and not visible and significant (Abzari \& Ghahfarokhi, (2007)).

Organizational intelligence and artificial intelligence indicate specific processes within an organization that is characterized by three features: interaction, consensus, and cooperation or collaboration features. Organizational intelligence means having a comprehensive knowledge of all the factors influencing the organization. Besides, organizational intelligence is presumed as having an in-depth knowledge of all factors such as customers, society and addressees, clients and competitors, economic environment, operations, and processes of an organization that make a significant impact on the quality of management and organizational decisions(Yolles, (2005)). Researches demonstrate that organizational intelligence is associated with positive results such as cordial behavior and good relations with colleagues and family (Rise, (1999)). Monder believes that characteristic capabilities, such as organizational intelligence, 
needs to be understood in terms of the true representations of the real world including working, family and community condition. Recent researches assume the organizational intelligence as a critical capability for the workplace (kafetsios, (2004)). Organizational intelligence must be considered as a consequence of a group of social symbols, organizational culture, and interaction of the members (kalkan, (2005)). From Helal's viewpoint (1997), organizational intelligence is the capacity of an organization to create and use knowledge to adapt to the environment or the market strategically. Organizational intelligence is like IQ, but it has been shaped in an organizational level.

Helal (2006) regards organizational intelligence as the performance result of the following five cognitive systems including organizational structure, culture, knowledge management, stakeholders' relations, and strategic processes. Vaylinsky (2000) introduces the organizational intelligence as the process of finding the problems, data collection, processing, interpreting, and associating the required technical political information in the decision-making process. In a more general definition focusing on the organization, Mumford and Gastavson have defined organizational intelligence as understanding the organization which is tantamount to a learning and creative system. Organizational intelligence was introduced in 1990s, for the first time, at Stanford University through studying 164 organizations in different countries and its relationship with organizational performance.

From Alberkht's perspective, organizational intelligence consists of seven dimensions including: 1) strategic vision 2) common fate 3) the desire to change 4) unity and agreement 5) spirit 6) application of knowledge 7) the performance pressure (Albrekht, (2002)).

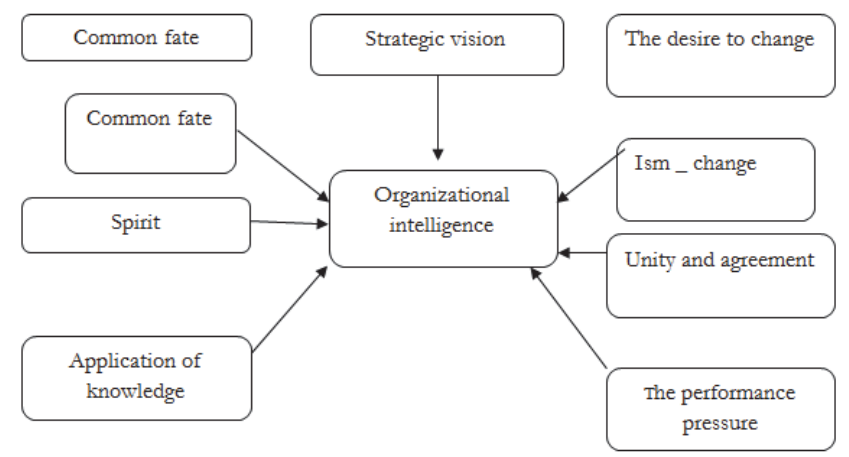

Figure 1: The index of organizational intelligence in Albrecht's view 2002.

Strategic vision: the strategic vision of any organization refers to the capacity of creating and asserting the aim. Each organization requires a theory, a concept, organizational principles, and a definition of what is done. Strategic vision refers to a principal pivotal vision that the whole employees accept it and are harmonized toward this vision. However, strategic vision is supposed to be revisable by the leaders and experts in annual meetings. Besides, the opportunities and threats caused by environmental factors need to be constantly reconsidered.

Common fate: employees consider themselves as an effective member of the organization. Also, managers take actions by the employees' participation in projects, programs, implementations, and evaluations. As a result, they recognize the organizational missions and get a sense of sympathy and solidarity toward the aims.

The desire to change: organizations that are flexible and more compatible with the environment can prosper and succeed more greatly. In such organizations, the employees are encouraged to invent and innovate better ways to do their work. Products and services continually evolve with changing the demands and the requirements of workplace.

Unity and agreement: in case some people work together without a set of rules, they will face problems and. When a group of people divide the duties and responsibilities to carry out their missions, they should organize themselves and interact with each other and their environment on the basis of a series of laws.

Spirit: in addition to the common fate, the element of feeling is indicative to a willingness and desire to work beyond the standard. In an organization with a low degree of feeling, employees just perform their own tasks correctly. However, in an organization with a high degree of feeling, employees make efforts beyond the expectations and their energy is constantly increasing.

Application of knowledge: the success or failure of organizations is based on the effective use of knowledge, information, and data. The ability to create, transfer, organize, share and apply knowledge in complex environments of 
the organizations has turned into a critical aspect of competitiveness. The ability to create, transfer, organize, share and apply knowledge in complex organizations has become a critical aspect of the competition.

Performance pressure: managers and professionals should not engage themselves solely with the executive functions of the company, since their success depends on the organization's strategic goals. In an intelligent organization, everyone is performs his or her own job duties because they believe in the validity of their aims. Leaders are able to improve and support the performance pressure. But, it will be highly influential when it is accepted as a series of necessary mutual expectations at work so as to cooperate in successes.

Organizational intelligence is a quantitative criterion for the efficiency of the organization in disseminating the information, decision-making, and implementation. Organizations' IQ like individuals' IQ can be measured. Intelligent organizations augment their mental capabilities the same as their physical capabilities (Piri, (2006)). Organizational intelligence regarded as the dynamic business window to the outside, which identifies organizational performance, increases efficiency, and hunts the unknown opportunities (Howson, (2008)). Hegin (2003) states that, in the present era of knowledge, organizations have realized that their life will not continue unless they employ a strategy for the management and valuation of their organizational knowledge (Asefzadeh \& Piri, (2004)).

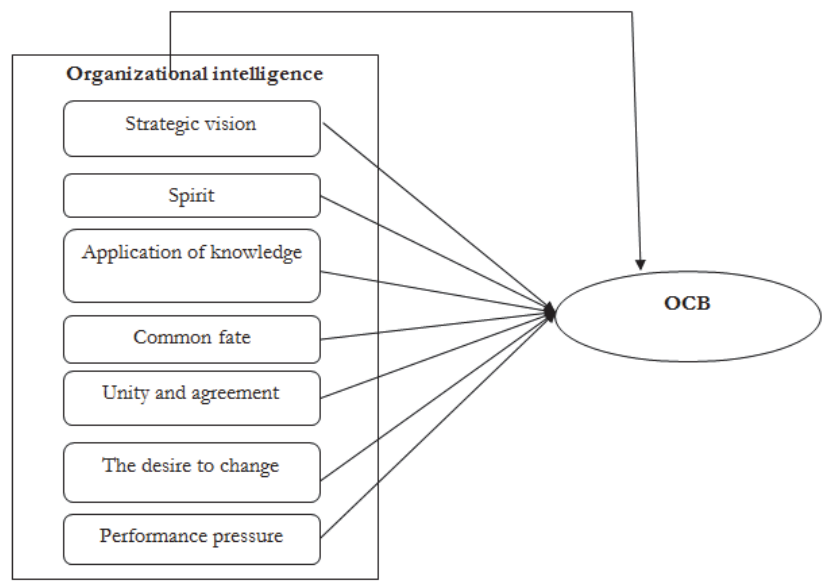

Figure 2: The conceptual model (from the theoretical fundamentals and previous studies)

\section{Research hypotheses}

\subsection{The main hypothesis:}

Organizational intelligence makes a significant impact on organizational citizenship behavior.

\subsection{Sub-hypotheses :}

1. Strategic vision makes a significant impact on organizational citizenship behavior.

2. Common fate makes a significant impact on organizational citizenship behavior.

3. The desire to change makes a significant impact on organizational citizenship behavior.

4. Spirit makes a significant impact on organizational citizenship behavior.

5. Unity and agreement makes a significant impact on organizational citizenship behavior.

6. Application of knowledge makes a significant impact on organizational citizenship behavior.

7. Performance pressure makes a significant impact on organizational citizenship behavior.

\section{The Research Methodology}

This study is both applicable and descriptive surveying regarding the aim and data collection, respectively. The statistical 
universe of this research includes the nurses of the state hospitals in Kermanshah Province, Iran. The statistical sample was determined 220 individuals by the means of Cochran Formula. Simple random sampling method has been applied in this study. In addition, the data have been collected through questionnaires that their information are illustrated in the table below.

Table 2. The research questionnaires data

\begin{tabular}{|l|l|c|}
\hline Variables & Reference & Item Number \\
\hline Citizenship behavior & Lee \& Allen(2002) & $22-31$ \\
\hline Organizational intelligence & Fulford and Enz(2009) & $1-21$ \\
\hline
\end{tabular}

\subsection{The Validity and reliability of the Questionnaire}

A number of experts' views were employed for assessing the validity and localizing the questionnaires. This evaluation focused primarily on content validity of the offered indices in order to measure the dimensions given in the research scheme. Moreover, Cronbach's alpha was applied for the reliability of the results illustrated in the table below:

Table 3: The reliability coefficient of the research variables

\begin{tabular}{|l|l|c|c|}
\hline Variables & Dimensions & Items number & Reliability coefficient \\
\hline \multirow{3}{*}{ Organizational } & Strategic vision & 3 & 0.0897 \\
\cline { 2 - 4 } & Common fate & 3 & 0.0931 \\
\cline { 2 - 4 } & The desire to change & 3 & 0.0904 \\
\cline { 2 - 4 } & Spirit & 3 & 0.0889 \\
\cline { 2 - 4 } & Unity and agreement & 3 & 0.0923 \\
\cline { 2 - 4 } & Application of knowledge & 3 & 0.900 \\
\cline { 2 - 4 } & Performance pressure & 3 & 0.0893 \\
\hline OCB & ------------ & 9 & 0.918 \\
\hline The questionnaire total & ----------- & 30 & 0.901 \\
\hline
\end{tabular}

As it is evident in the table above, the Cronbach's alpha coefficients of all variables and dimensions are greater than 0.70 which indicates the fact that the reliability of questionnaire is confirmed.

\subsection{The Structural Model of the Main Hypothesis of the Research}

The model in standard estimation status

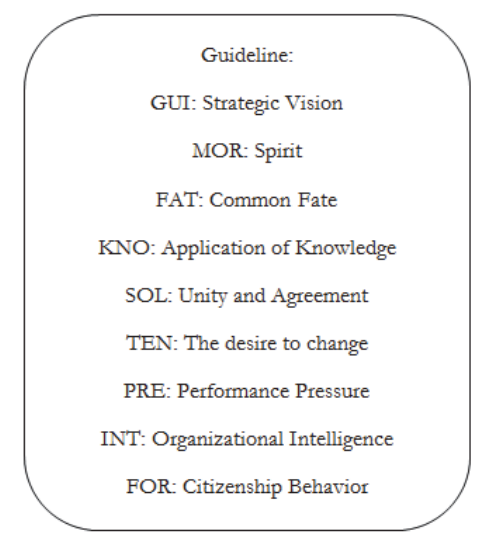

Figure 3: The structural model of the main hypothesis in the standard estimation status. 


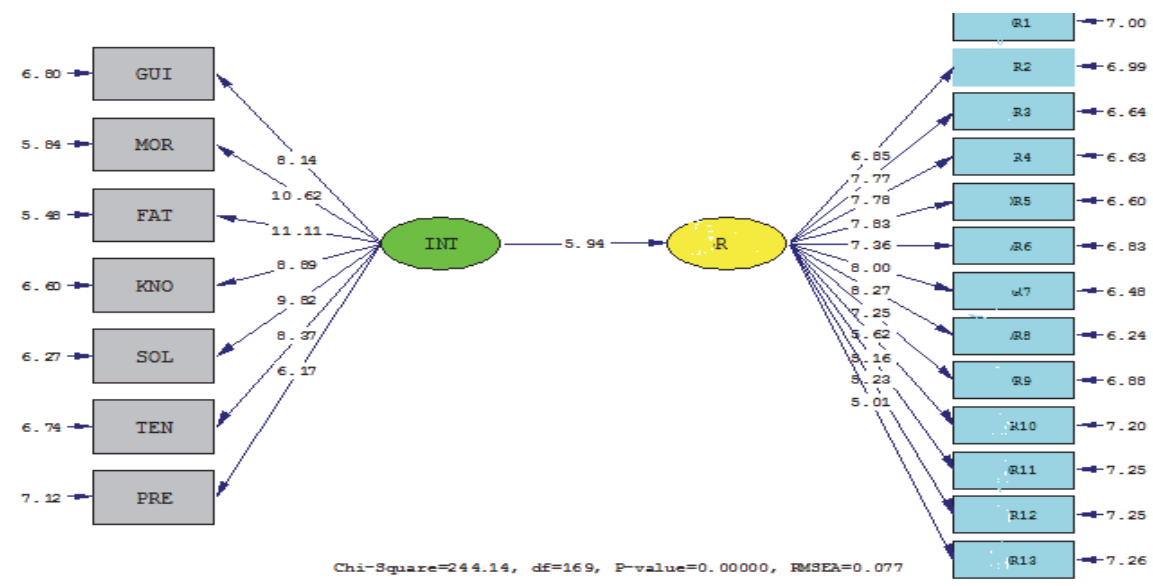

Figure 4: The structural model of the main research hypothesis in the significant coefficients status.

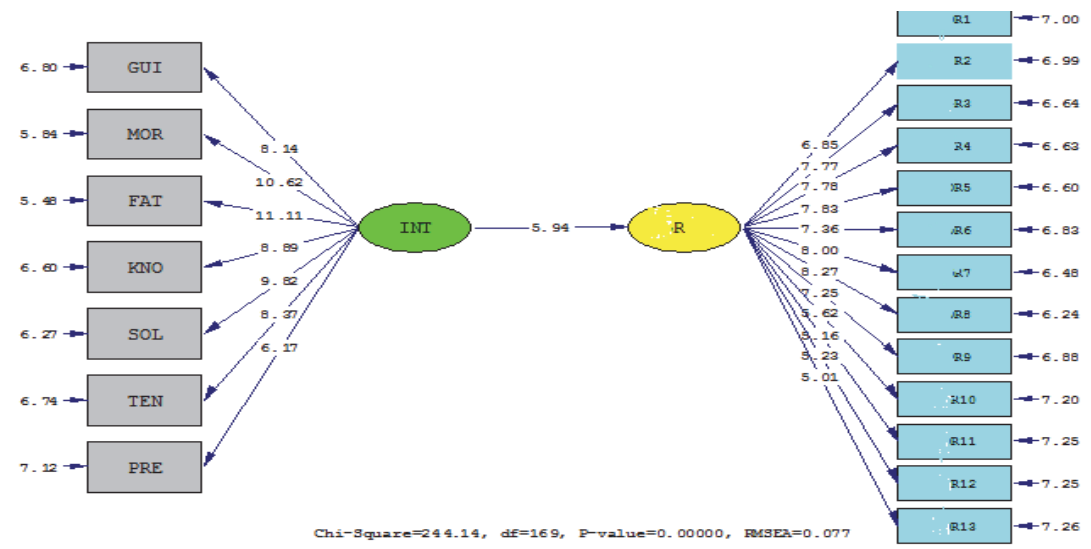

\subsection{Examining the Structural Model Fitting of the Main Research Hypothesis}

Indices such as NFI, GFI and AGFI are considered as the indices of the model fitness. In these indices, the higher the value is, the model is better fit. Table 4 contains the most important indices of the model fitting and shows that all of these indices demonstrate the model fitness with the observed data, since the ratio of chi-square over the degree of freedom is less than 3 , RMSEA index is less than 0.08 , and the remaining indices are acceptable. In other words, the research model is acceptable and significant.

Table 4: The indices of the model fitting

\begin{tabular}{|l|lc|}
\hline \multirow{2}{*}{ The name of the index } & \multicolumn{2}{|c|}{ The obtained values } \\
\cline { 2 - 3 } Chi-square over the degree of freedom & The obtained value & The permitted limit \\
GFI & 0.44 & lower than 3 \\
RMSEA & 0.07 & higher than90\% \\
CFI & 0.96 & lower than90\% \\
AGFI & 0.93 & higher than90\% \\
\hline
\end{tabular}




\subsection{Examining the Main Research Hypothesis}

To test the main research hypothesis, the structural equations (LISREL software) were employed and the results are shown in Table 5. As it is manifest, because the significance number (T-Value) is greater than 1.96, the main hypothesis is confirmed. In other words, organizational intelligence makes a significant impact on the organizational citizenship behavior. In addition, the type of the influence is positive, since the effect coefficient between both variables is 0.75 . In another word, organizational intelligence makes a direct, positive, and significant impact on the organizational citizenship behavior.

Table 5: Examining the main research hypothesis

\begin{tabular}{|l|lll|}
\hline The research hypotheses & Path coefficient & t-statistics & Result \\
\hline Organizational intelligence---->organizational citizenship behavior & 0.75 & 5.94 & confirmed \\
\hline
\end{tabular}

\subsection{The Structural Model of the Research sub-hypotheses}

The model in the standard estimation status

Figure 5: The structural model of the research sub-hypotheses in the standard estimation status.

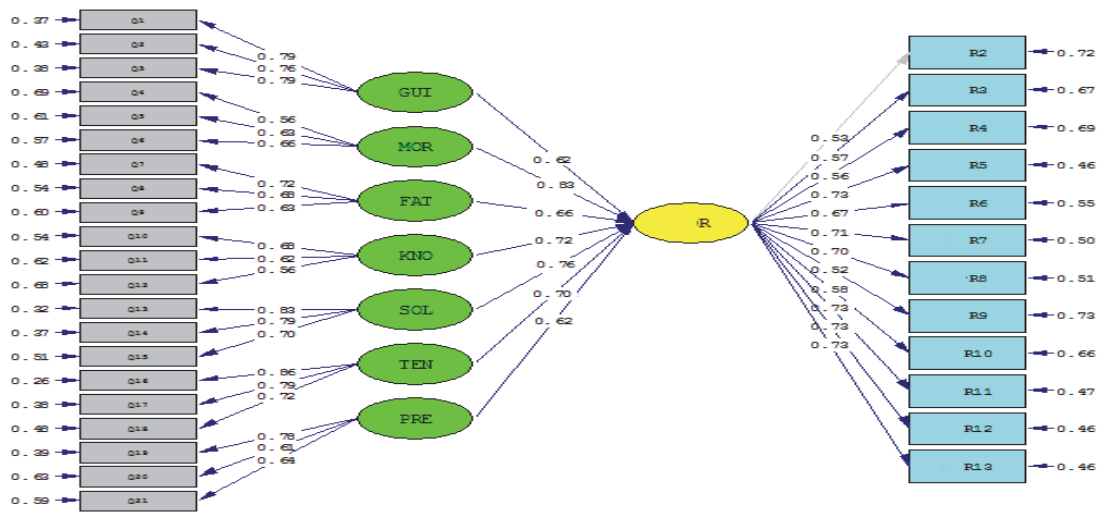

The Model in the significant coefficients status

Figure 6: The structural model of the research sub-hypotheses in the significant coefficients status.

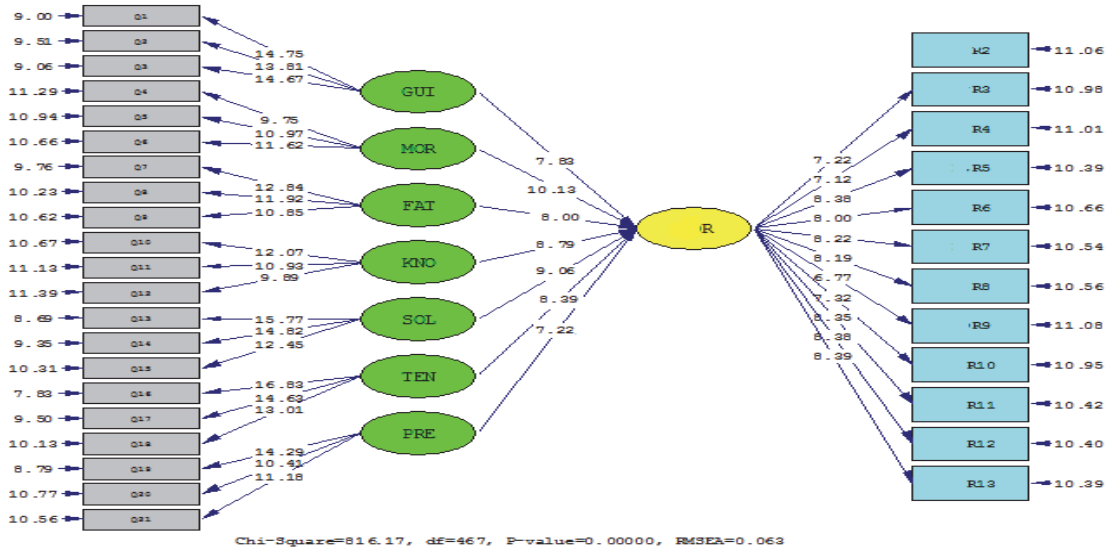




\subsection{Examining the Structural Model Fitting of the Research Sub-Hypotheses}

Indices of the structural model fitting are illustrated in Table 6 which includes the most important indices of the model fitting. As it evident, all these indices demonstrate the fitness of the model with the observed data.

Table 6: The indices of the model fitting

\begin{tabular}{|l|lc|}
\hline \multirow{2}{*}{ The name of the index } & \multicolumn{2}{|c|}{ The obtained values } \\
\cline { 2 - 3 } Chi-square over the degree of freedom & 1.74 & The permitted limit \\
GFI & 0.98 & lower than 3 \\
RMSEA & 0.063 & higher than90\% \\
CFI & 0.94 & higher than90\% \\
AGFI & 0.95 & higher than90\% \\
\hline
\end{tabular}

\subsection{Examining the Research Sub-Hypotheses}

In order to test the research sub-hypotheses structural equation method (LISREL software) has been utilized and the results are shown in Table 7. As it is manifest, because the significance number (T-Value) is greater than 1.96, the whole sub-hypotheses are confirmed. Since all the effect coefficients of the variables are positive, the type 0 the influence is positive.

Table 7: Examining the research sub-hypotheses

\begin{tabular}{|l|ccl|}
\hline The research hypotheses & Path coefficient & t-statistics & Result \\
\hline Strategic vision ---> The OCB & 0.62 & 7.83 & confirmed \\
Common fate ----> The OCB & 0.66 & 8.00 & confirmed \\
Desire to change----> The OCB & 0.70 & 8.39 & confirmed \\
Spirit ----> The OCB & 0.83 & 10.13 & confirmed \\
Unity and agreement----> The OCB & 0.76 & 9.06 & confirmed \\
Application of Knowledge----> The OCB & 0.72 & 8.79 & confirmed \\
Performance pressure ---> The OCB & 0.62 & 7.22 & confirmed \\
\hline
\end{tabular}

\section{Conclusions and Recommendations}

Nowadays, the designers of the organizational systems often focus their efforts on achieving the strategic goals and competitive advantage. By designing such systems, they intend to create the survival base or leading the organizations in today's markets. What is important in this regard seems to be emphasized by the designers is the importance of the human resources in these systems and their role in achieving the desired objectives. Therefore, the human resources as the most prominent competitive advantage in the development of entrepreneurship and subsequently the differentiation of the organizations have been regarded more than ever. In today's competitive world, organizations need employees who go beyond the official requirements of their jobs; otherwise, organizations will not be able to develop the effectiveness and improve the performance. These are extra-role behaviors and are not considered as an official job description and if the employees do or not to do them, they will not be encouraged or punished by the organization. The presence of the OCB will have positive consequences for the organization such as increasing the productivity, higher performance, efficiency, improving positive relationships between the employees, reducing the maintenance costs, etc.

Although the individual and motivational differences are effective in the organizational citizenship behaviors, it should be noted that organizational citizenship behavior are not inherent behaviors and are not considered as the personality traits. Although personality variables such as emotional stability, agreeableness and extraversion are good examples for predicting the OCB, the organizational variables such as support, justice, and leadership behaviors play a remarkable role in exposing the organizational citizenship behavior. Thus the organizations need to care that the organizational citizenship behavior is not a personality trait to enable the organizations to select their workforce on its basis. 


\section{References}

Asefzadeh, Saeed; Piri, Zakieh (2004). "Key activities in knowledge management", Journal of Babol University of Medical Sciences, 55. No. 4, Page 6

Aghajani, Hassan Ali; Samadi, Miarkolayi, Hossein; Samadi Miarkolayi, Hamzeh. State Management, No. (5) Volume 2, p. 1-18

Abzari, Mehdi; Sattari Ghahfarokhi (2007). "The relationship between organizational intelligence and organizational culture in Isfahan Mobarakeh Company". The Collection of the International Conference articles on Knowledge Management

Piri, Zakieh (2006). "A model for OI, the fourth annual meeting of health services management students across the country", Tehran

Jafari, Parivash; Faghihi, Alireza (2009). "The components of the organizational intelligence in the research and educational planning organizations". Journal of knowledge and research in educational science. Educational planning, Islamic Azad University, Khourasgan Branch, No. 23, autumn 2009. Page 66

Kordnayij, A. (2004) "customer-orientation: the secret of the success of transcendental organizations", Journal of Management Studies, No. 43 and 44, pp153-183.

Reichheld, F., Sasser, W. E. Jr. (1990); Zero defection: quality comes to services; Harvard Business Review, Vol.68, SeptemberOctober, pp.105-111

Hui C., Lam S.S.K., Schaubroeck J.; (2001) Can good citizens lead the way in providing quality service?; Academy of Management Journal, Vol.44, No.5, pp.988-995

Organ D.W., Konovsky M.; (1989) Cognitive versus affective determinants of organizational citizenship behavior; Journal of Applied Psychology, Vol.74, pp.157-164

Robbins S.P.; (2001) Organizational Behavior; Prentice-Hall: Upper Saddle River, NJ,

Dyne L.V, Ang S.; (1998) Organizational citizenship behavior of contingent workers in Singapore; Academy of Management Journal, Vol. 41, No. 6, pp.692-703

Organ D.W.; (1988) Organizational citizenship behavior: The good soldier syndrome; Lexington, MA: Lexington Books,

Hui C., Law K.S., Chen Z.X.; (1999) A structural equation model of the effects of negative affectivity, leader-member exchange, and perceived job mobility on in-role and extra-role performance: A Chinese case; Organizational Behavior and Human Decision Processes, Vol.77, pp.3-21

Podsakoff P.M., MacKenzie S.B., Paine J.B., Bachrach D.G.; (2000) Organizational citizenship behaviors: A critical review of the theoretical and empirical literature and suggestions for future research; Journal of Management, Vol.26, pp.513-563

15 Organ D.W., Ryan K.; (1995) A meta-analytic review of attitudinal and dispositional predictors of organizational citizenship behavior; Personnel Psychology, Vol.48, pp.775-802

Wang H., Law K.S., Hackett R., Wang D., Chen Z.X.; (2005) Leader-member exchange as a mediator of the relationship between transformational leadership and followers' performance and organizational citizenship behavior; Academy of Management Journal ,Vol.48, No.3, pp.420-432

Podsakoff P.M., MacKenzie S.B., Bommer W.H.; (1996) Transformational leader behaviors and substitutes for leadership as determinants of employee satisfaction, commitment, trust, and organizational citizenship behaviors; Journal of Management, Vol.22, pp.259-298

Netemeyer R., Boles T.S., Mckee D.O., McMurrian R.; (1997) an investigation into the antecedents of organizational citizenship behaviors in a personal selling context; Journal of marketing, Vol.61, pp.85-98

MacKenzie S.B., Podsakoff P.M., Fetter R.; (1991) OCB and objective productivity as determinants of managerial evaluations of salespersons' performance; Organizational Behavior and Human Decision Processes, Vol. 50, pp.123-150

Bolino, M.C., Turnley, W.H. and Bloodgood, J.M. (2002), "Citizenship behavior and the creation of social capital in organizations", Academy of Management Review, Vol. 27, No. 4.pp 5-522.

Morrison, E.W. (1996), "Organizational citizenship behavior as a critical link between HRM practices and service quality", Human Resource Management, Vol. 35, pp. 493-512.

Podsakoff, P., Mackenzie, S., Paine, J. and Bachrach, D. (2000), "Organizational citizenship behaviors: a critical review of the theoretical and empirical literature and suggestions for further research", Journal of Management, Vol. 26 No. 3, pp. 513-63.

Yoon, M. and Suh, J. (2003), "Organizational citizenship behaviors and service quality as external effectiveness of contact employees", Journal of Business Research, Vol. 56, pp. 597-611.

Van Dyne L, Graham JW, Dienesch RM., (1994), "Organizational citizenship behavior: construct redefinition, measurement, and validation", Academy of Management Journal, Vol. 37 No.4, pp.765- 802.

Brackett, M.A, Mayer, J. D. \& Warner, R.M. (2004).Emotional intelligence and its relation to everyday behavior. Personality individual differences, 36, 1387-1402

26-Howson, Cindi (2008). Successful Business Intelligence- secrets to Making BI a killer App, McGraw-Hill companies

kalkan, v. (2005), orgutsel zeka vabilgivretimi (iibf.ogu. Tr/ kongre/ bildiriler/10-1.pdf)

Albrekht, Karl (2002). Organizational intelligence and knowledge management, the executive perspective. Retrieved. 2006, from. http://www.karl Albrecht.com

kafetsios, k. (2004). Attachment and organizational intelligence abilities across the life course personality and individual differences. Journal of applied psychology, 326-336

Rise, C.L. (1999).A quantitative study of emotional intelligence and its impact on team performance. Unpublished master's thesis, Pepperdine University, Malibu, CA.

Yolles, M. (2005). "Organizational Intelligence”, Journal of workplace learning, 17 (1), pp.99-114 